\title{
ORIGIN OF THE ASCHOFF BODY
}

\author{
BY \\ BERNICE G. WEDUM \\ Rheumatic Fever Study, Frederick, Maryland \\ AND \\ JOHN W. MCGUIRE \\ Photography Section, Medical Arts and Photography Branch, Division of \\ Research Services, National Institutes of Health, Bethesda, Md.
}

Rheumatic fever has been compared with tuberculosis (Thorel, 1910; Fahr, 1930), Hodgkin's disease (Aschoff and Tawara, 1906; Gross, Loewe, and Eliasoph, 1929), and hypersensitivity reactions (Swift, 1924; Klinge, 1933). The ultimate, complete explanation of its pathogenesis must explain why it has presented such varying aspects to such profound students of the disease. The present study concerns the nature of its most specific pathological manifestations, the Aschoff body of the heart.

Evidence is presented that the Aschoff body is derived from the larger lymphatic vessels of the heart; the central core, which may be present, is composed of precipitated lymph and necrotic protoplasm. These granulomata form at points of mechanical stress, especially under the endocardium and in the region of the intramyocardial coronary arteries. Damage to cardiac muscle and connective tissue is secondary to the lymphoedema which follows obstruction of the lymphatic vessels by the proliferating endothelial cells. It is most prominent at points of mechanical trauma, notably at the point of closure of the heart valves, where vegetations form.

The existence of a rheumatism of the heart was first clearly defined by Dundas (1809), although Jenner (1789) had written an account of the association (his manuscript was subsequently lost), and it had also been mentioned by Pitcairn (1797) and Odier (1806). In his second edition, Odier (1811) reported two cases of rheumatic adhesive pericarditis in a footnote, and concluded, "But what is difficult to understand is that this complete adherence of the two organs which are naturally detached one from the other did not in any way disturb the circulation."

Thus at the beginning of the 19th century the question was asked why the heart failed in rheumatic carditis, and this question was to occupy students of rheumatic fever for the next 150 years.

Ludwig Aschoff directed his attention to this problem in his first paper (1904), seeking for evidence that the conduction system of the heart was affected in acute rheumatism and was responsible for the functional disorder, an idea previously advanced by Peter (1891). Aschoff found no evidence to support such a theory in the three cases which were the subject of his first paper, but Aschoff and Tawara (1906), in their monograph on the failing heart, described one case with considerable involvement of the bundle of Hiss. They came to the conclusion that the basic disorder was an anaemic necrosis of the myocardium caused by perivasculitis of the blood vessels supplying the muscle. They had found in the adventitia of the blood vessels "peculiar nodules which were specific for rheumatic carditis ... developed by an aggregation of conspicuously large elements with one or more abnormally large, slightly indented or polymorphous nuclei. The aggregation of these cells often takes the form of a fan or rosette. The periphery is formed by the large nuclei, and the centre by apparently necrotic protoplasm, staining here weaker and somewhat different"' (Aschoff, 1904).

The greatness of Aschoff's contribution lies not only in his recognition of a granuloma specific for rheumatic carditis, but also in his recognition that the damage to the myocardium was in some manner secondary to the specific lesion in the connective tissue. Poynton (1899) had also appreciated that "the function of cardiac muscle is damaged in a peculiar way, rather than destroyed by the rheumatic poison". (The term "peculiar disease of the heart" had been used by Dundas (1809), Aschoff wrote of "peculiar nodules", and years later MacCallum (1924) was to mention "lymphatic channels filled with lymphocytes which form a peculiar and rather conspicuous feature", and that rheumatic fever was 
caused by a specific infectious agent of some peculiar kind (MacCallum, 1925). In identical language these able students of the disease expressed their awareness of something unusual and not heretofore encountered in rheumatic carditis.)

With only a few dissenting voices, the specificity of the granuloma described by Aschoff for rheumatic carditis was widely accepted. The exact origin of the characteristic giant cell remained in doubt. The majority considered it to be some type of connective tissue or endothelial cell (Aschoff, 1904, 1906; Geipel, 1905; Fraenkel, 1912; Swift, 1924; Letulle, Bezançon, and Weil, 1926; Clawson, Bell, and Hartzell, 1926). A few (Huzella, 1914; Whitman and Eastlake, 1920; Murphy, 1960) considered this giant cell to be derived from the myocardial fibre itself. Others, while holding to the view that the Aschoff cell was a connective tissue cell, believed that giant cells could also arise from the myocardium (Saigo, 1908; Letulle, Bezançon, and Weil, 1926; Wagner and Tedeschi, 1955). The views of many investigators have been summarized by McEwen (1932).

The important question debated during the next 25 years was whether the central core of the granuloma described so carefully by Aschoff as "necrotic protoplasm" was in fact the primary lesion. Klinge (1933), in his monumental study of all forms of rheumatism, concluded that exudation was the primary process, consisting of a specific type of damage to collagen fibrils. He also stated, however, that proliferation and exudation might occur simultaneously and, in agreement with Talalajew (1929), that perhaps in the heart the primary process was cellular proliferation. Aschoff (1939) published pictures showing undamaged fibrils in early Aschoff bodies and maintained that rheumatic carditis was essentially a proliferative disease of cells. Rheumatic fever, nevertheless, became known as a collagen disease and the search for the aetiologic agent became an inquiry into the mechanism by which this alteration in collagen was produced. Still unanswered was the question how myocardial function was so profoundly altered as a result of connective tissue damage.

For more extensive reviews the writings of Itard (1824), Eulenberg (1854), Besnier (1877), Janot (1902), Gallavardin (1908), Jacki (1919-20), Bezançon and Weil (1926), Sacks (1926), Paul (1928), Clawson (1929), Klinge (1933), Gross and Ehrlich (1934), Wilson (1940), Baggenstoss (1953), Murphy $(1943,1960)$ should be consulted, together with the section on rheumatic fever in the Rheumatism and Arthritis Review (1962).

For the past 20 years the writer (B.G.W.) has been concerned with the pathology of rheumatic heart disease, assuming that the Aschoff cell was derived from some type of connective tissue cell. Interest centred chiefly in the mode of formation of this cell, whether by mitotic or amitotic division of nuclei, which would suggest a mechanism of pathogenesis involving DNA, or by fusion, which would suggest an alteration in the cell membrane. Studies on the aetiology of rheumatic fever in progress in our laboratory included the use of tissue culture of left auricular appendages obtained at surgery for mitral stenosis. With the appearance of the monograph by Murphy (1960), suggesting the origin of the Aschoff cell from the myofibre itself, it seemed essential to re-investigate this question in order to be certain that our experimental approach was sound. Connective tissue cells migrate in tissue culture, but the myofibre does not.

\section{Present Investigations}

It seemed that the pathology of rheumatic carditis would be seen most clearly in patients dying in the course of a first attack of rheumatic fever. An effort was made, therefore, to obtain material from as many early cases as possible. Such cases are rare, but it was possible to collect six with three additional cases of children of similar age dying of causes unrelated to the heart to serve as controls (Table, overleaf, p. 129). Details are given in the Appendix, p. 139.

\section{Method}

The co-author (J.W.McG.) pointed out that details could be seen on large colour transparencies which were not apparent under the microscope. A series of eighty $8 \times 10$-inch colour transparencies, some at magnifications as high as 2,450 , was taken of the sections, exploring each system of the heart. It was then possible to examine the transparencies, using a view box, and to study them over long periods, sometimes with the aid of a hand lens.

\section{Results}

In the course of these studies a dilated lymphatic vessel, its endothelial lining cells exhibiting unusual features in that they resembled early Aschoff cells, was noted between two blood vessels (Figs 1 and 2, opposite). A search for lymphatic vessels in sections of normal hearts revealed none which could be discerned, nor were there any special stains available to differentiate lymphatic vessels from surrounding connective tissue.

An inquiry into the anatomy of the lymphatic 


\section{ORIGIN OF THE ASCHOFF BODY}

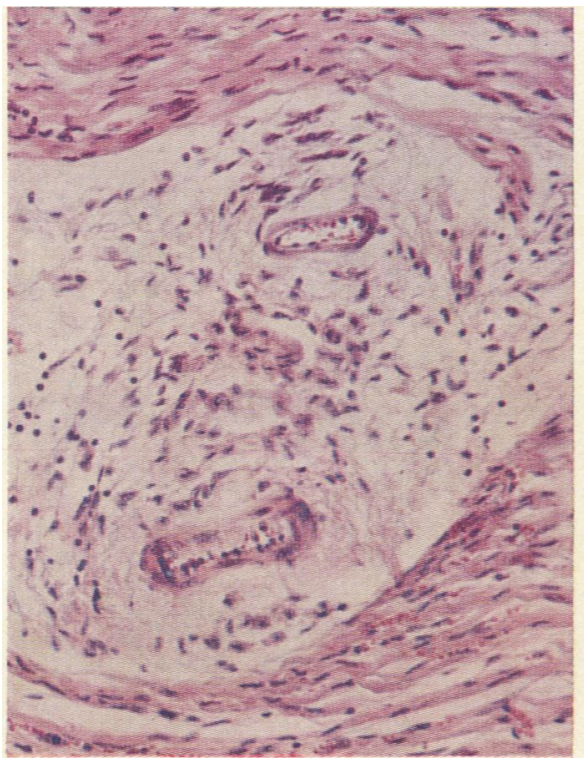

Fig. 1.-Lymphatic vessel between two blood vessels, showing swelling of endothelial cells with central condensation of nuclear chromatin. Case $1 . \times 150$.

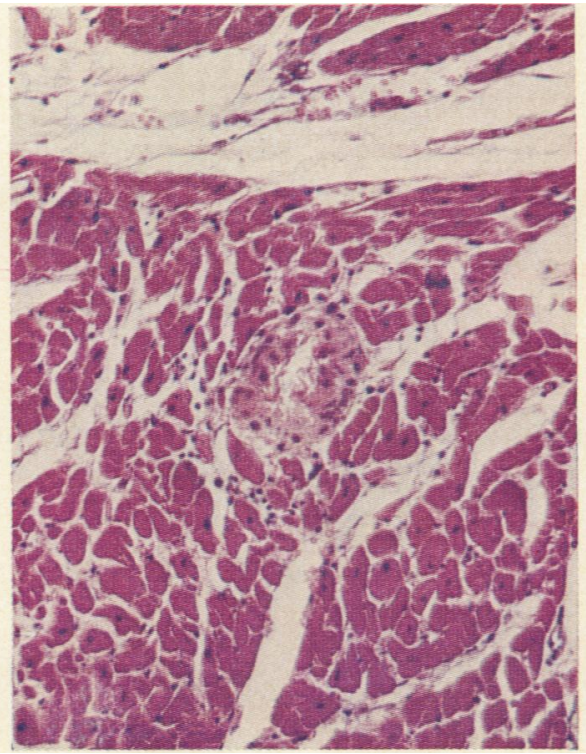

Fig. 10.-Aschoff body forming from lymphatic channel cut in crosssection with roseate structure. Case $4 . \times 175$.

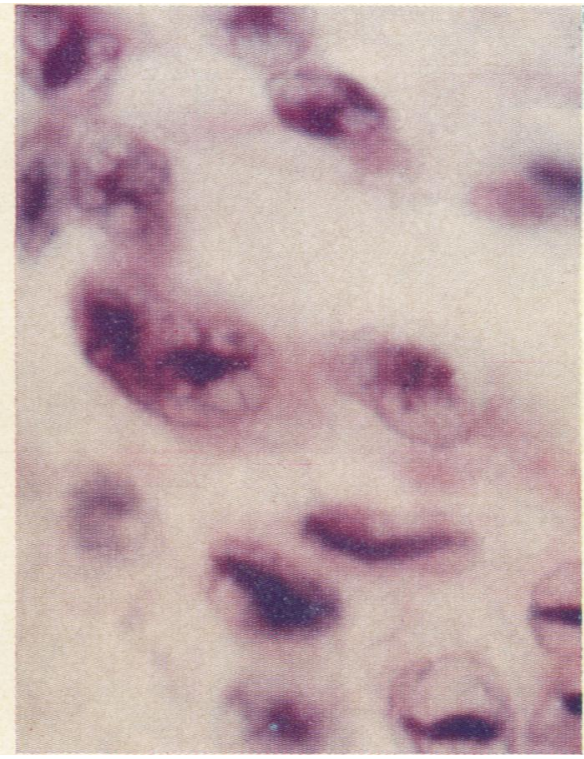

Fig. 2.-Lymphatic vessel in Fig. 1 under higher power, showin details of formation of early Aschoff cells. Case 1. $\times 1,500$.

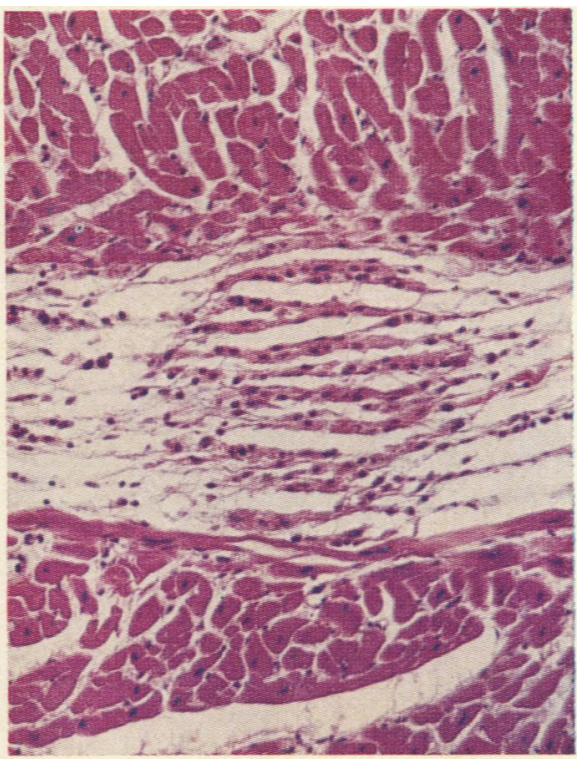

Fig. 12.-Aschoff body forming from lymphatic channels cut in longitudinal section with parallel "ribbons" of cells. Case $4 . \times 175$. 
TABLE

PARTICULARS OF SIX PATIENTS AND THREE CONTROLS

\begin{tabular}{|c|c|c|c|c|c|c|c|}
\hline $\begin{array}{l}\text { Case } \\
\text { No. }\end{array}$ & Sex & $\begin{array}{l}\text { Age } \\
\text { (yrs) }\end{array}$ & Race & Hospital & Physician & History & Diagnosis \\
\hline \multicolumn{8}{|c|}{ Rheumatic Cases } \\
\hline 1 & - & - & - & $\begin{array}{l}\text { Armed Forces Institute of } \\
\text { Pathology, } \\
\text { Washington, D.C. }\end{array}$ & Dr. W. Manion & 一 & Acute rheumatic carditis \\
\hline 2 & $\mathbf{F}$ & $6 \frac{1}{2}$ & Col. & $\begin{array}{c}\text { Children's Hospital, } \\
\text { Philadelphia, Pa. }\end{array}$ & Dr. P. Vanace & Dr. S. Friedman & Rheumatic pancarditis \\
\hline 3 & $\mathbf{F}$ & 4 & Col. & $\begin{array}{l}\text { Armed Forces Institute of } \\
\text { Pathology, } \\
\text { Washington, D.C. }\end{array}$ & Dr. W. Manion & $\begin{array}{l}\text { Desartment of Path- } \\
\text { ology, Louisiana } \\
\text { State University, } \\
\text { School of Medicine, } \\
\text { Dr. H. C. McGill }\end{array}$ & Rheumatic pancarditis \\
\hline 4 & $\mathbf{M}$ & 10 & Wh. & $\begin{array}{l}\text { Armed Forces Institute of } \\
\text { Pathology, } \\
\text { Washington, D.C. }\end{array}$ & Dr. W. Manion & $\begin{array}{l}\text { New York University } \\
\text { Medical Centre, } \\
\text { Dr. N. Cooper }\end{array}$ & $\begin{array}{l}\text { Acute rheumatic myo- } \\
\text { carditis } \\
\text { Rheumatic pneumonitis }\end{array}$ \\
\hline 5 & $\mathbf{M}$ & 5 & Col. & $\begin{array}{l}\text { Children's Hospital, } \\
\text { Washington, D.C. }\end{array}$ & Dr. P. Vera Cruz & Dr. H. Wigger & Acute rheumatic carditis \\
\hline 6 & $\mathbf{M}$ & 3 & Ind. & $\begin{array}{l}\text { Belcourt Indian Hospital, } \\
\text { N. Dakota }\end{array}$ & Dr. G. Laqueur & Dr. G. Laqueur & $\begin{array}{l}\text { Rheumatic pancarditis } \\
\text { with rheumatic pneu- } \\
\text { monia; cardiac massage }\end{array}$ \\
\hline \multicolumn{8}{|c|}{ Non-Rheumatic Control Cases } \\
\hline 1 & $\mathbf{M}$ & 4 & Wh. & $\begin{array}{l}\text { Brackenridge Hospital, } \\
\text { Aust in, Texas }\end{array}$ & Dr. E. Gilbert & Dr. E. Gilbert & $\begin{array}{l}\text { Broncho-pneumonia; } \\
\text { Cardiac arrest; } \\
\text { Cardiac massage }\end{array}$ \\
\hline 2 & $\mathbf{F}$ & 5 & Wh. & $\begin{array}{l}\text { Congenital Heart Disease } \\
\text { Research and Training } \\
\text { Centre, Chicago, Ill. } \\
\text { Mount Sinai Hospital, } \\
\text { New York }\end{array}$ & Dr. M. Lev & Dr. M. Lev & $\begin{array}{l}\text { Wilm's tumour right } \\
\text { kidney }\end{array}$ \\
\hline 3 & $\mathbf{F}$ & 6 & Wh. & $\begin{array}{l}\text { Johns Hopkins Hospital, } \\
\text { Baltimore, Md. }\end{array}$ & Dr. J. Frost & Dr. J. Frost & Cerebellar astrocytoma \\
\hline
\end{tabular}

Case 1: Figs 1-4, 24-26.

Case 2: Figs 14, 15, 17, 22, 23.

Case 3: Figs 20, 21

Case 4: Figs 5-13, 16

Case 6: Figs 18, 19.

vessels of the heart led us to the writings of Patek (1939) and Roberts (1959). According to the latter, the lymphatic vessels of the heart consist of four subdivisions: the subendocardial plexus, the myocardial plexus, the epicardial plexus, and the lymphatic drainage channels. The subendocardial plexus is made up of small lymphatic channels forming a branching and anastomotic network with large meshes lying in the subendocardial connective tissues of all four chambers of the heart. The myocardial plexus comprises a more voluminous system of lymphatic capillaries and small channels, which form a network very closely similar to the blood vascular plexus of capillaries and vessels throughout the myocardium. The lymphatic capillaries lie close to the blood capillaries in the interstitial spaces between adjacent muscle fibres and drain into larger lymphatic channels, which follow the venules to the interstitial connective tissue septa. The epicardial plexus is loosely arranged in the subepicardial connective tissue. All the lymphatic drainage channels usually unite in a single trunk which joins a left mediastinal plexus of lymphatic vessels.

Re-examination of the sections from the available cases indicated that the topography of the distribution of Aschoff bodies closely followed that of the lymphatic channels described by Roberts (1959). Closer study suggested that the Aschoff body itself might be a diseased lymphatic channel, ultimately converted into a solid granuloma, sometimes with a central core of precipitated lymph and necrotic protoplasm. In Figs 3 to 26 an attempt is made to illustrate the sequence of events leading from early endothelial changes within the lymphatic vessels to the Aschoff body. 


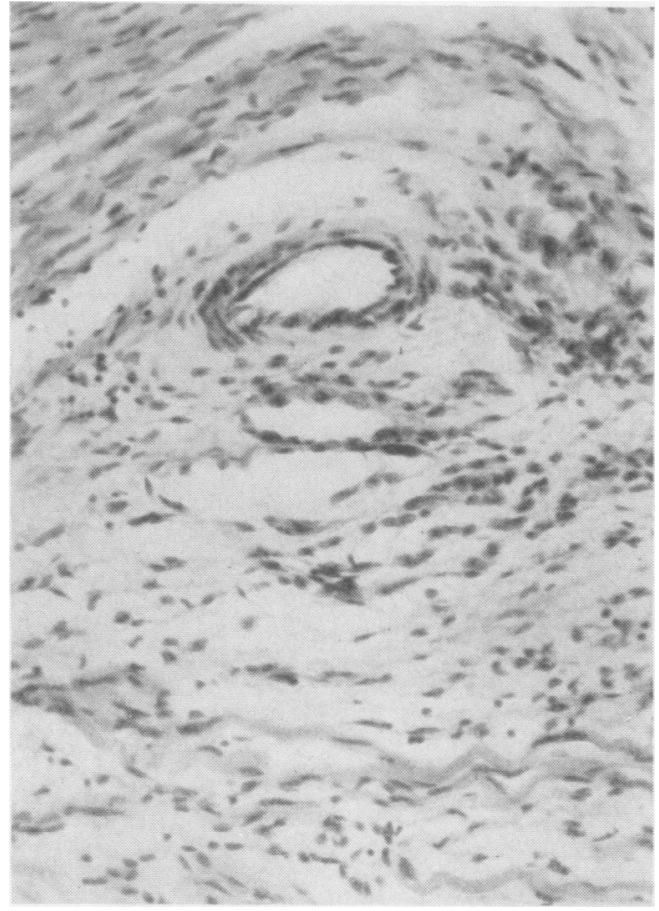

Fig. 3.-Distended lymphatic channels near small vessel. Case 1. $\times 175$.

Initially the nuclei of the delicate, flat endothelial cells lining the lymphatic channels increase in volume (Figs 3 and 4); the primary event appears to be this change in the nucleus. Central condensation of the chromatin ensues with simultaneous swelling of the entire cell, the cytoplasm becoming finely and uniformly granular and strongly eosinophilic. Very early, more than one nucleus is seen in the endothelial cell; this would appear to be a result of nuclear division, although in a careful search for mitotic figures in Aschoff cells only one was found (Fig. 5). (The original slide was examined by Dr. Yu Hin Tjio, who confirmed this observation.)

The lymphatic channel remains recognizable as such for a short period only (Fig. 6, opposite). The lumen of the vessel becomes progressively replaced by accumulated cytoplasmic debris and proteinaceous material (Figs 7 and 8, opposite). A central core may thus result, consisting of granular eosinophilic amorphous material (Fig. 9, opposite).

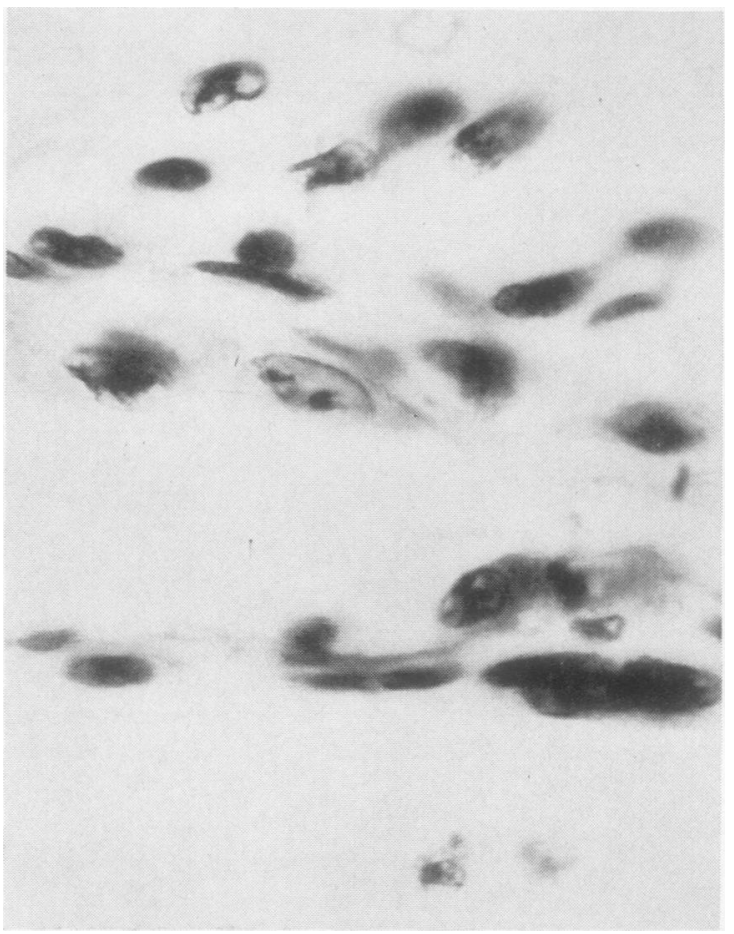

Fig. 4.-Lymphatic vessels in Fig. 3, showing swelling of nuclei of endothelium. One multinucleated cell is present. Case $1 . \times 1,040$.

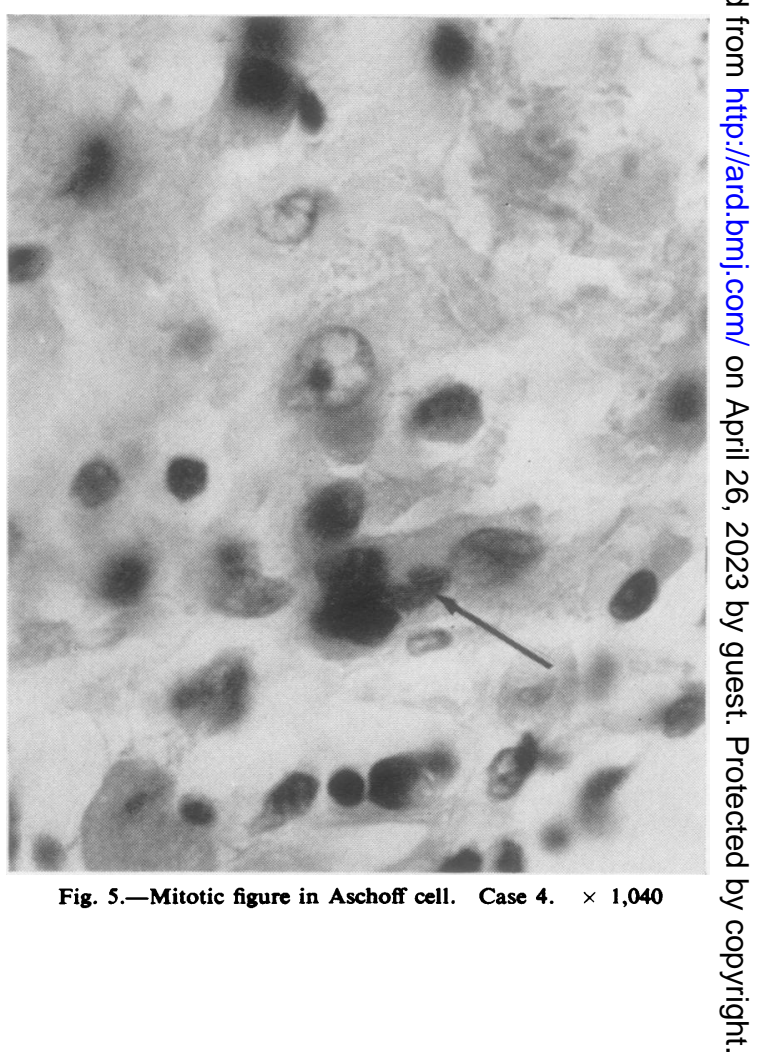




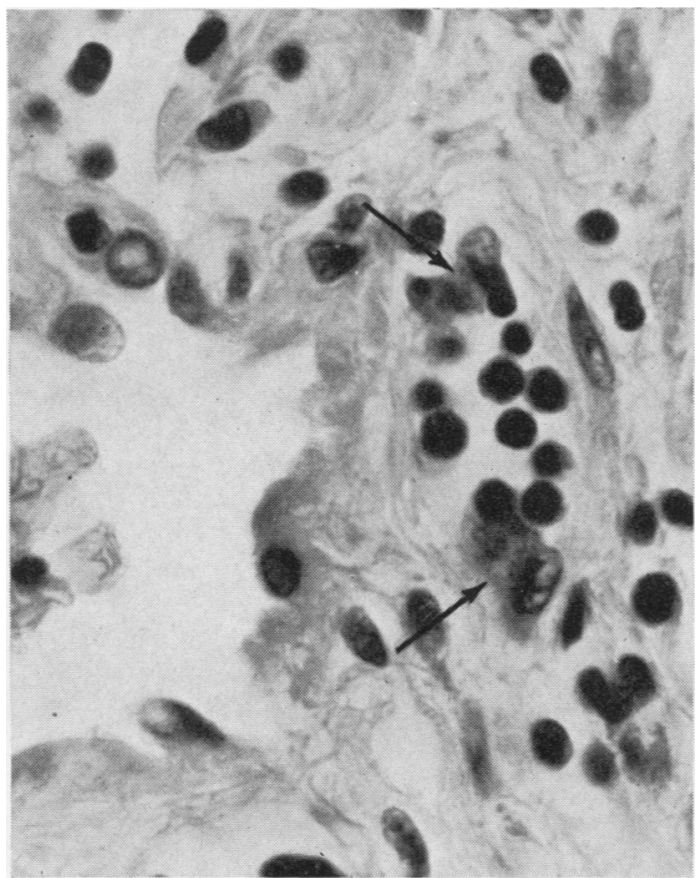

Fig. 6. - Lymphatic vessel near arteriole, showing two Aschoff cells forming from endothelial cells. Case 4. $\times 1,040$.

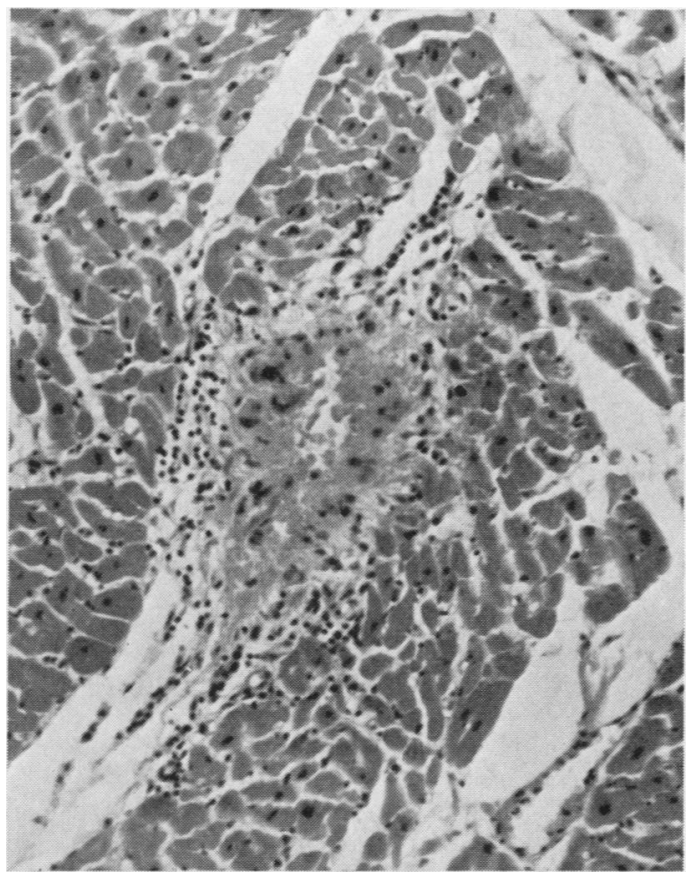

Fig. 8.-Lymphatic channel forming early Aschoff body. Note distended lymphatic capillaries. Case $4 . \times 175$.

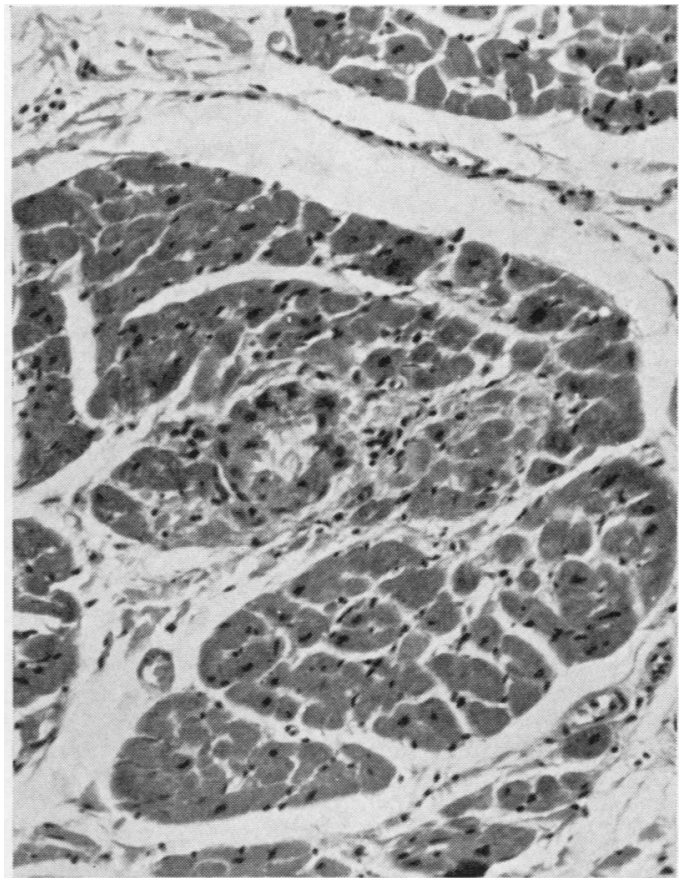

Fig. 7.-Aschoff body forming from lymphatic vessel. Case 4. $\times 175$.

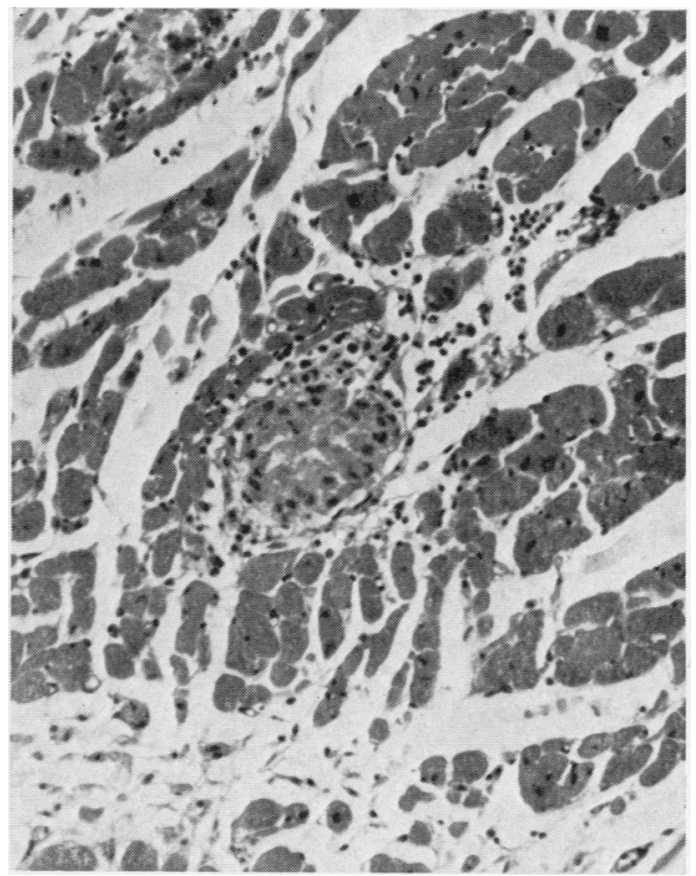

Fig. 9.-Aschoff body forming from lymphatic vessel, showing core of precipitated lymph and cell protoplasm. Case $4 . \times 175$. 


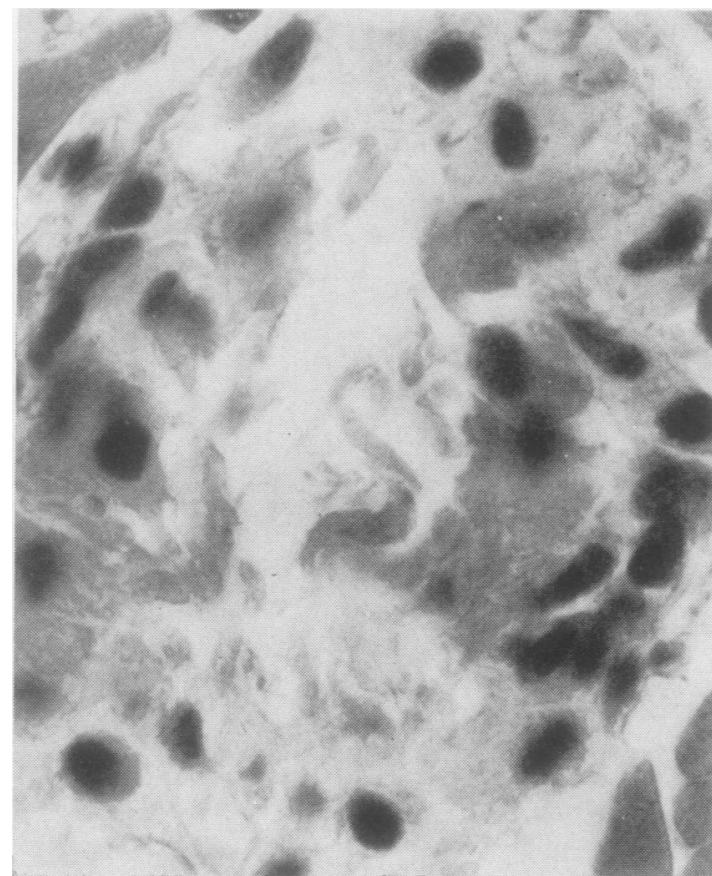

Fig. 11.-Details of early Aschoff body shown in Fig. 10. Case 4. $\times 1,040$.

In cross-section the early Aschoff body resembles a roseate structure (Fig. 10 (col. pl.), and Fig. 11), while in longitudinal section the effect is that of parallel "ribbons" of cells (Fig. 12 (col. pl.), and Fig. 13). The derivation of this granuloma from a lymphatic channel gradually becomes more difficult to discern (Figs 14 and 15) as the swollen

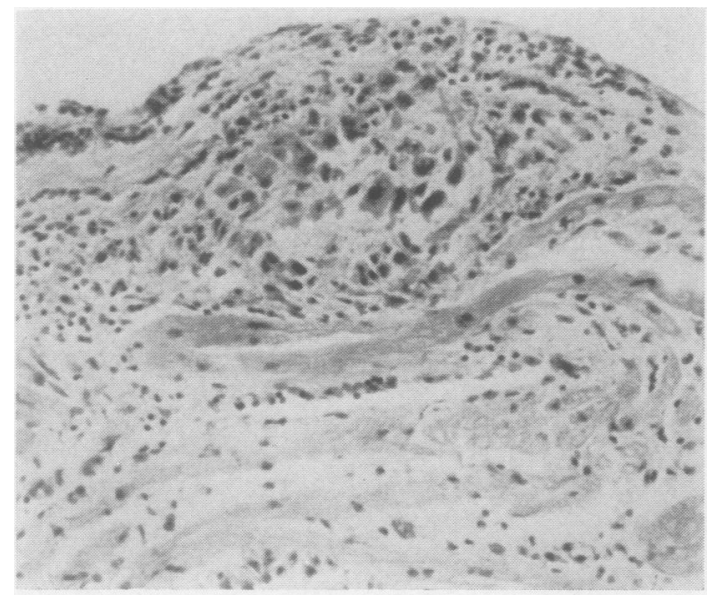

Fig. 14.-Aschoff body close to ventricular endocardium. The lymphatic channel may be only faintly discerned. Case $2 . \times 175$.

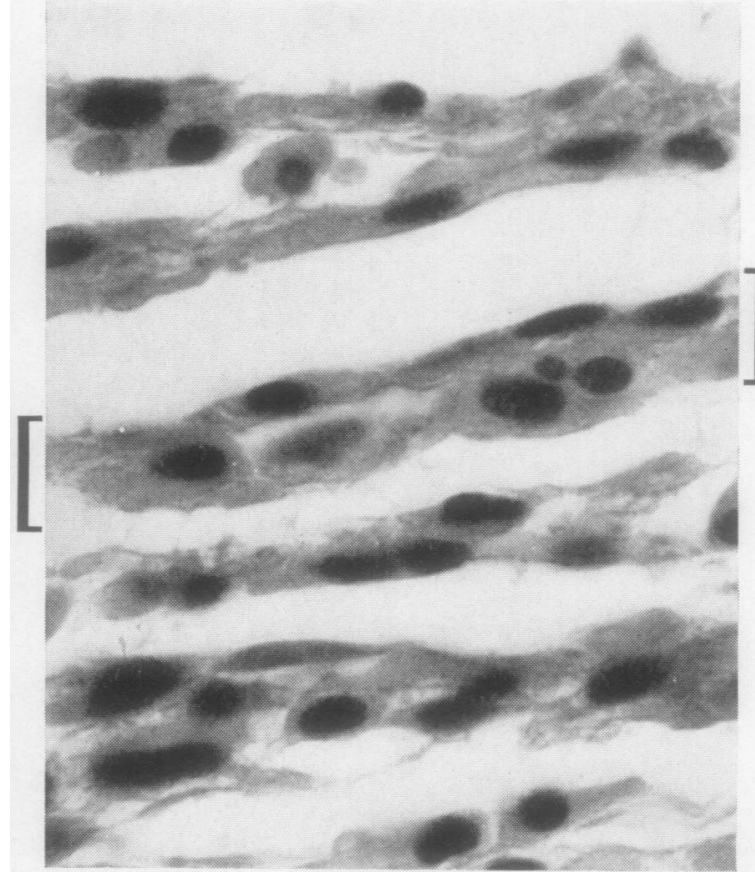

Fig. 13.-Detail of early Aschoff body shown in Fig. 12. Case 4 . $\times 1,040$.

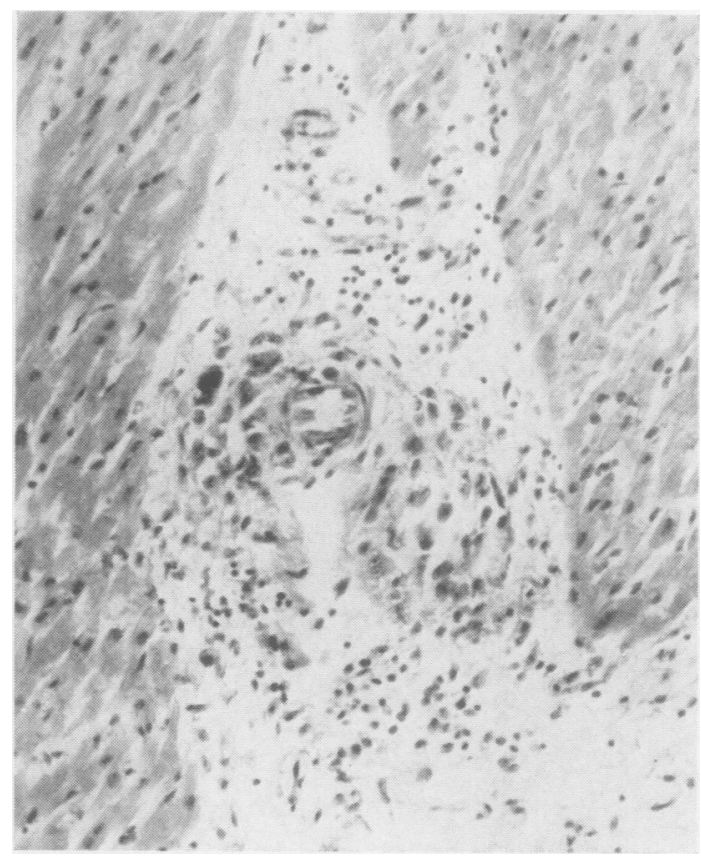

Fig. 15.-Aschoff body near small blood vessel, showing disappearance of lumen of lymphatic channels. Case $2 . \times 175$. 
cells with their proliferating nuclei are desquamated into the lumen; ultimately a solid mass of cells results (Fig. 16).

The endocardium is swollen two or three times its normal thickness. In the subendocardial lymphatic plexus, channels may be identified as such only occasionally; indirect evidence that they are involved is provided, however, by the distended lymphatic capillaries which radiate out on either side of the bands of flattened Aschoff bodies which appear to be derived from this plexus (Fig. 17). These capillaries contain lymphocytes, polymorphonuclear leucocytes, and larger cells with eosinophilic cytoplasm, which are occasionally multinucleated.

The pericardium is markedly oedematous and two or three times its normal thickness. Distended lymphatic channels may be seen particularly well in Case 6 (Figs 18 and 19, overleaf). The endothelial cells show the same swelling of nucleus and cytoplasm and occasionally have two or three nuclei. Large multinucleated Aschoff cells are not often seen, and only two Aschoff bodies were identified, both in the adventitia of the coronary sinus in Cases 1 and 6.

The lymphoedema resulting from the blockade of the lymphatic vessels by the proliferating endothelial cells appears to result in further damage

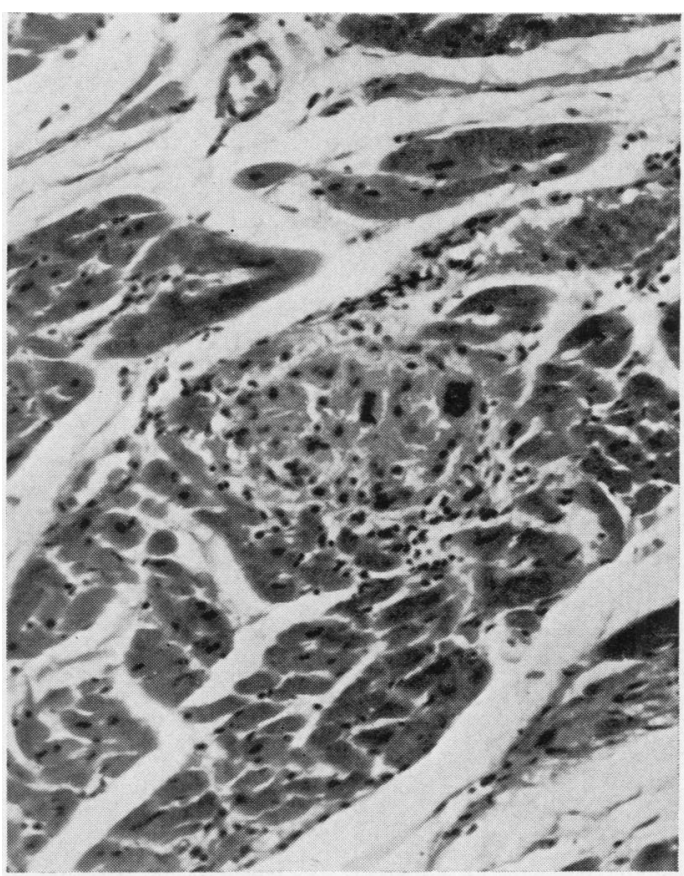

Fig. 16.-Solid granuloma derived from lymphatic channel; fullydeveloped Aschoff body. Case $4 . \times 175$. to the heart.

The nucleus of the myofibre may be seen to be swollen, with the chromatin re-arrangement typical of the true Anitschkow myocyte. The cross striations may be lost and the parenchyma gradually disappear, leaving in the path of the muscle track the more durable nuclei. These may be present in apparently larger numbers than would be accounted for by the muscle track, suggesting an attempt at division and regeneration. Occasionally there are clumps of degenerating muscle cells which closely resemble the true Aschoff cell (Fig. 20, overleaf). These changes in the muscle are found most often in the immediate vicinity of Aschoff bodies. The myofibrils in other areas show no changes when compared with the control cases, with the exception of Cases 1 and 6. In Case 1 changes are found throughout the section-a fine granulation of the sarcoplasm, unevenness of staining properties, and separation of the muscle fibres, apparently by oedema. A number of the nuclei of the myofibrils in Case 6 have the characteristics of the true Anitschkow myocyte.

The coronary arteries show separation of the adventitial fibres which is apparently due to oedema. Where larger Aschoff bodies lie adjacent to them, the

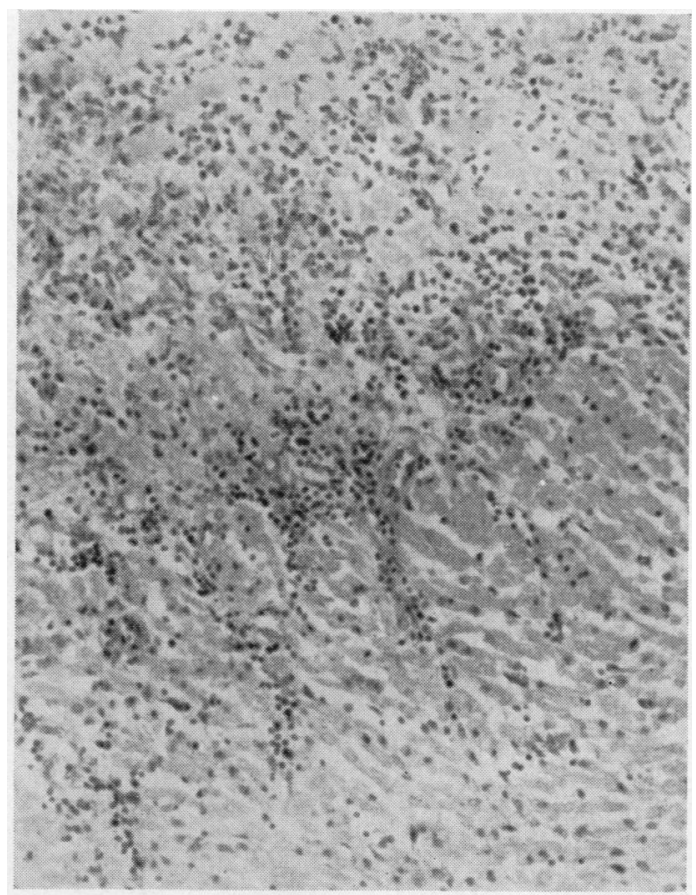

Fig. 17.-Left auricle, showing lymphatic capillaries radiating out from subendocardial lymphatic plexus into auricular myocardium. Case 2. $\times 175$. 


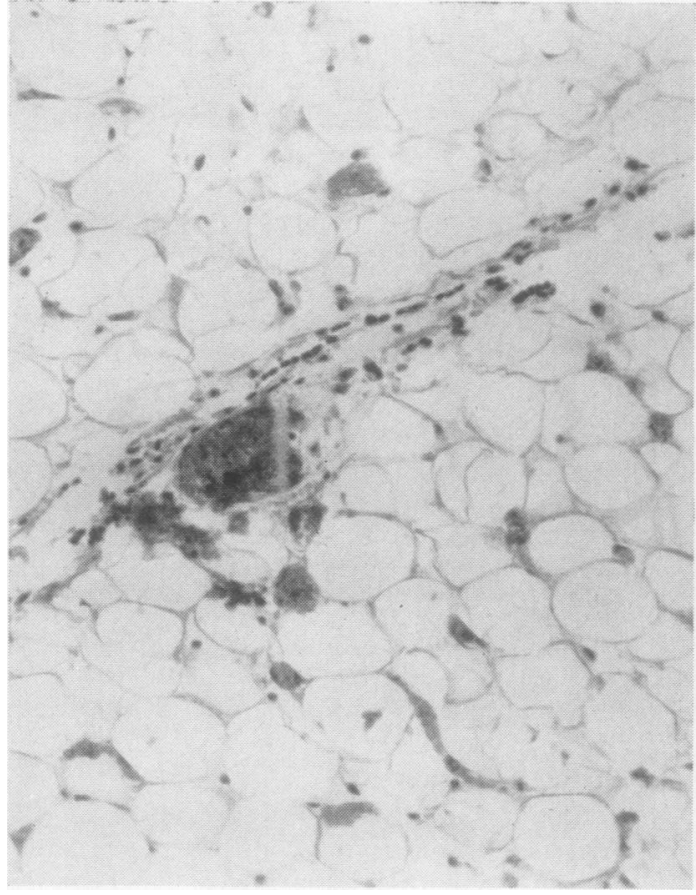

Fig. 18.-Lymphatic channel in pericardium. Case $6 . \times 175$.

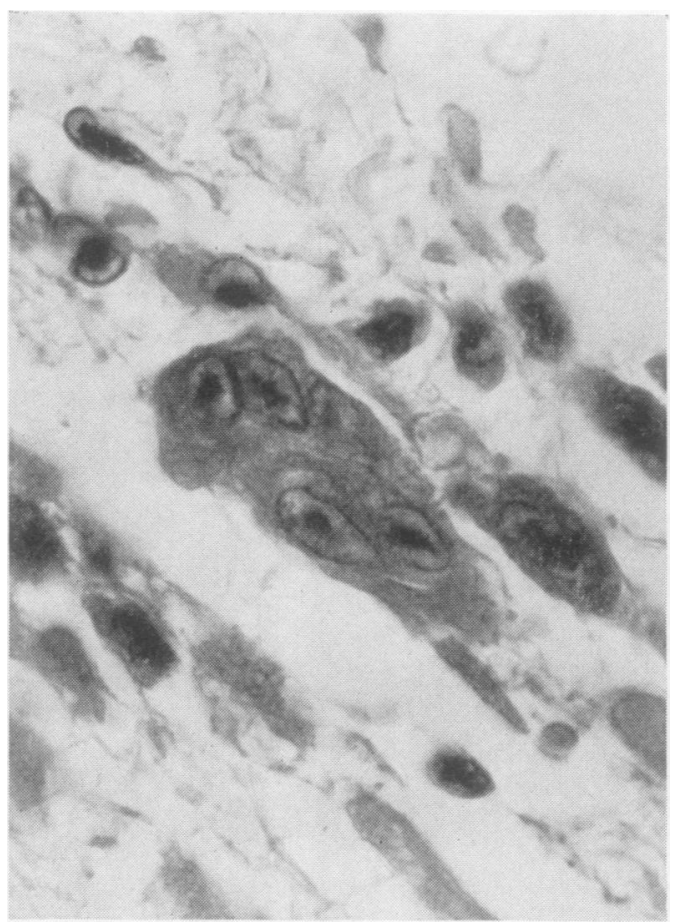

Fig. 20.-Clump of degenerating muscle cells resembling Aschoff cell. Case 3. $\times 1,040$.

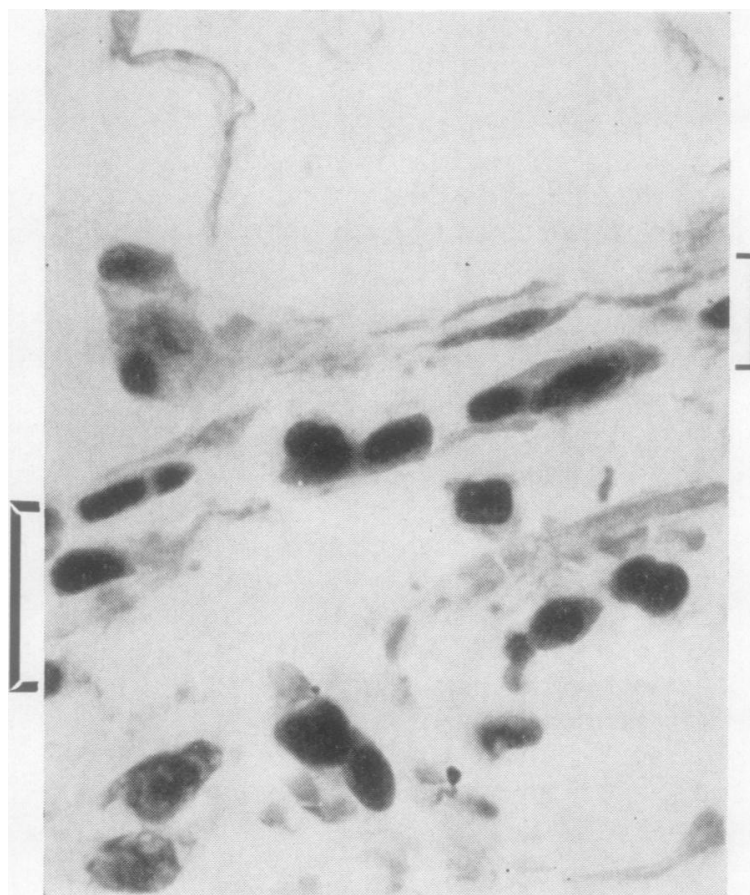

Fig. 19.-Lymphatic endothelial cells lining channel shown in Fig. 18. Compare with Fig. 13. Case $6 . \times 1,040$.

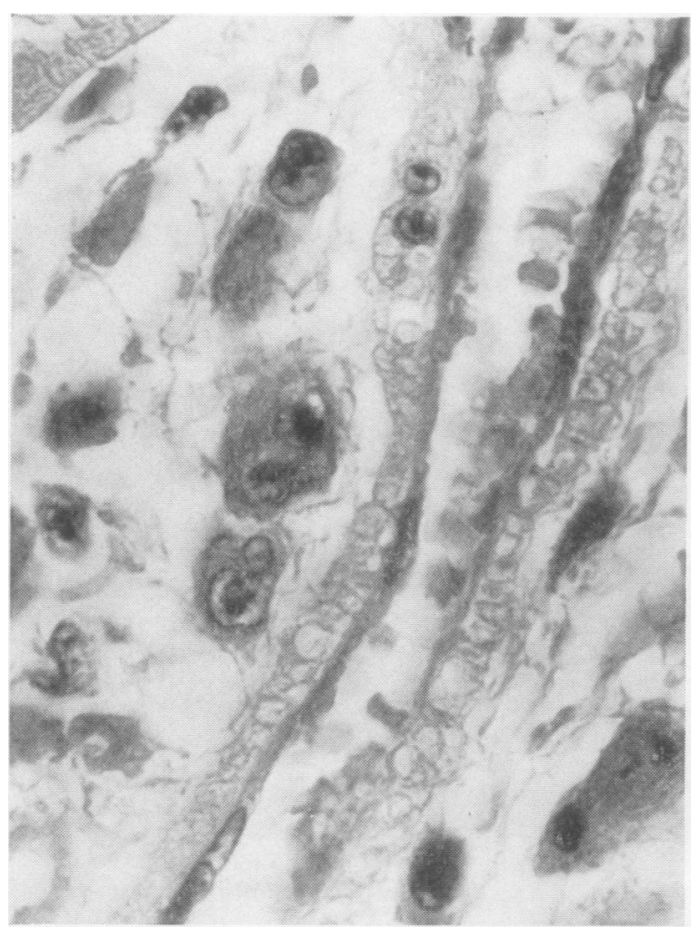

Fig. 21.- Intramyocardial small artery, showing normal media and adventitia. Early Aschoff body indenting vessel. Case 3. $\times 1,040$ 
endothelium of the intima occasionally shows slight swelling, and in Case 3 separation of the constituents of the media is sometimes noted. For the most part, however, the blood vessels show little change even in the vicinity of Aschoff cells (Fig. 21, opposite). Although the capillaries are engorged with blood, the capillary endothelium is normal.

In the connective tissue an increase in the number of fibroblasts is sometimes seen, especially in the region of Aschoff bodies. At points of mechanical trauma, damage to the oedematous connective tissue may occur; the delicate fibrils become indistinct and eosinophilic, with lymphocytes and eosinophils between them. The mitral valve in Case 2 is swollen to two or three times its normal thickness, when compared with the control cases. Several distinct lymphatic vessels are present just below the endocardium (Fig. 22) and at the point of closure a small vegetation is seen (Fig. 23). A moderate number of Aschoff cells appear in the aortic valve in Case 5.

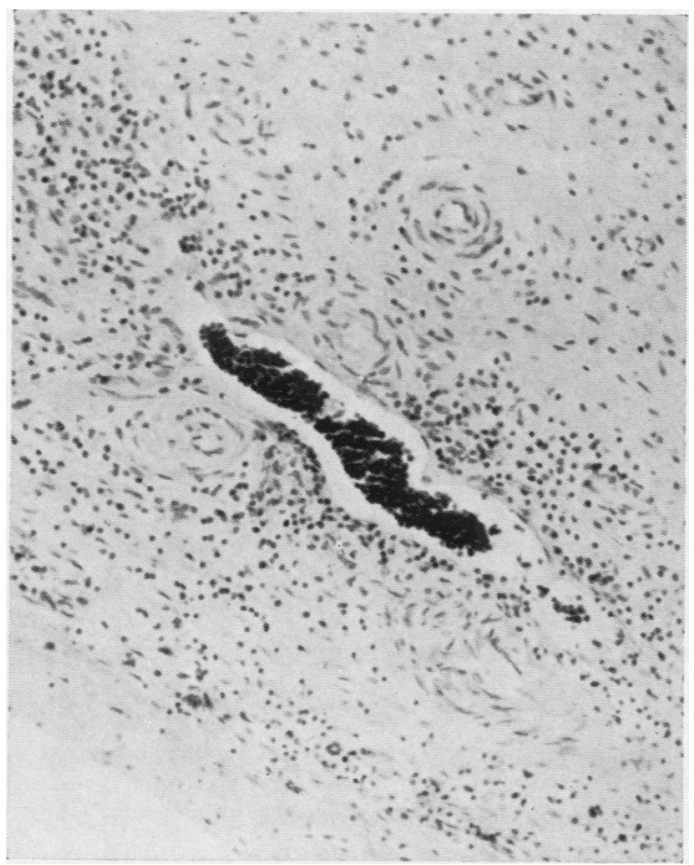

Fig. 22.-Lymphatic vessel in mitral valve. Case $2 . \quad \times 175$.
Fig. 24 (overleaf) shows the principal types of damage in early rheumatic carditis.

An Aschoff body is forming from a lymphatic channel (Fig. 25, overleaf).

The connective tissue between two vessels which seem to be arterioles appears to have been compressed between the two vessels; the ground substance is amorphous and there is lymphocytic and eosinophilic infiltration (Fig. 26, overleaf). Muscle tracks in the immediate vicinity show loss of parenchyma with persistence of nuclei.

The limited amount of material presented, all stained with haematoxylin and eosin, did not permit us to draw definite conclusions concerning the conduction system. It lies close to the subendocardial lymphatic plexus, however, and changes in its function are manifested early in rheumatic carditis by changes in the PR-interval of the electrocardiogram.

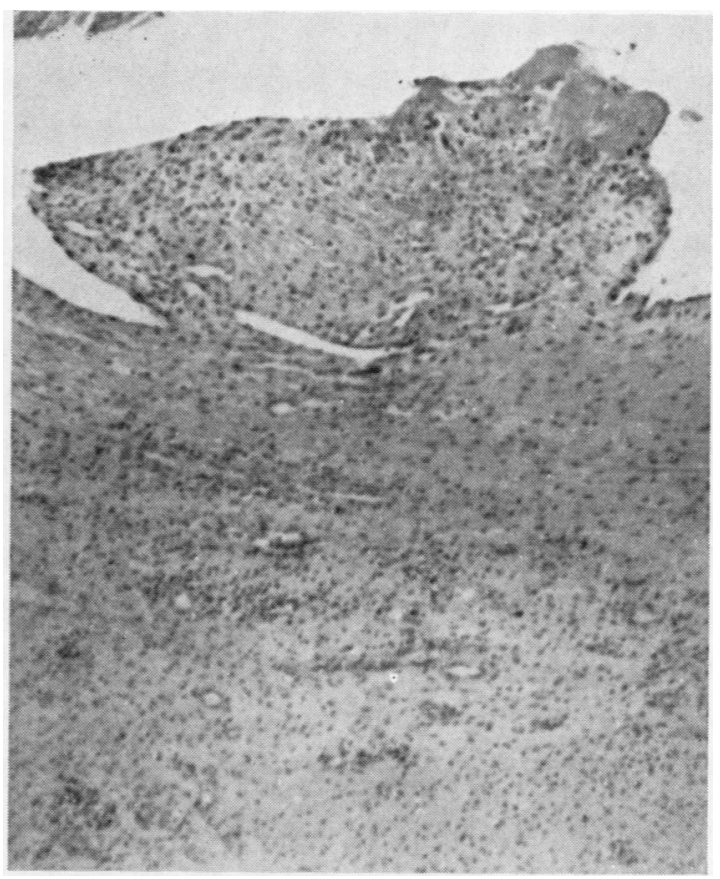

Fig. 23.-Vegetation on mitral valve. Case $2 . \quad \times 175$. 


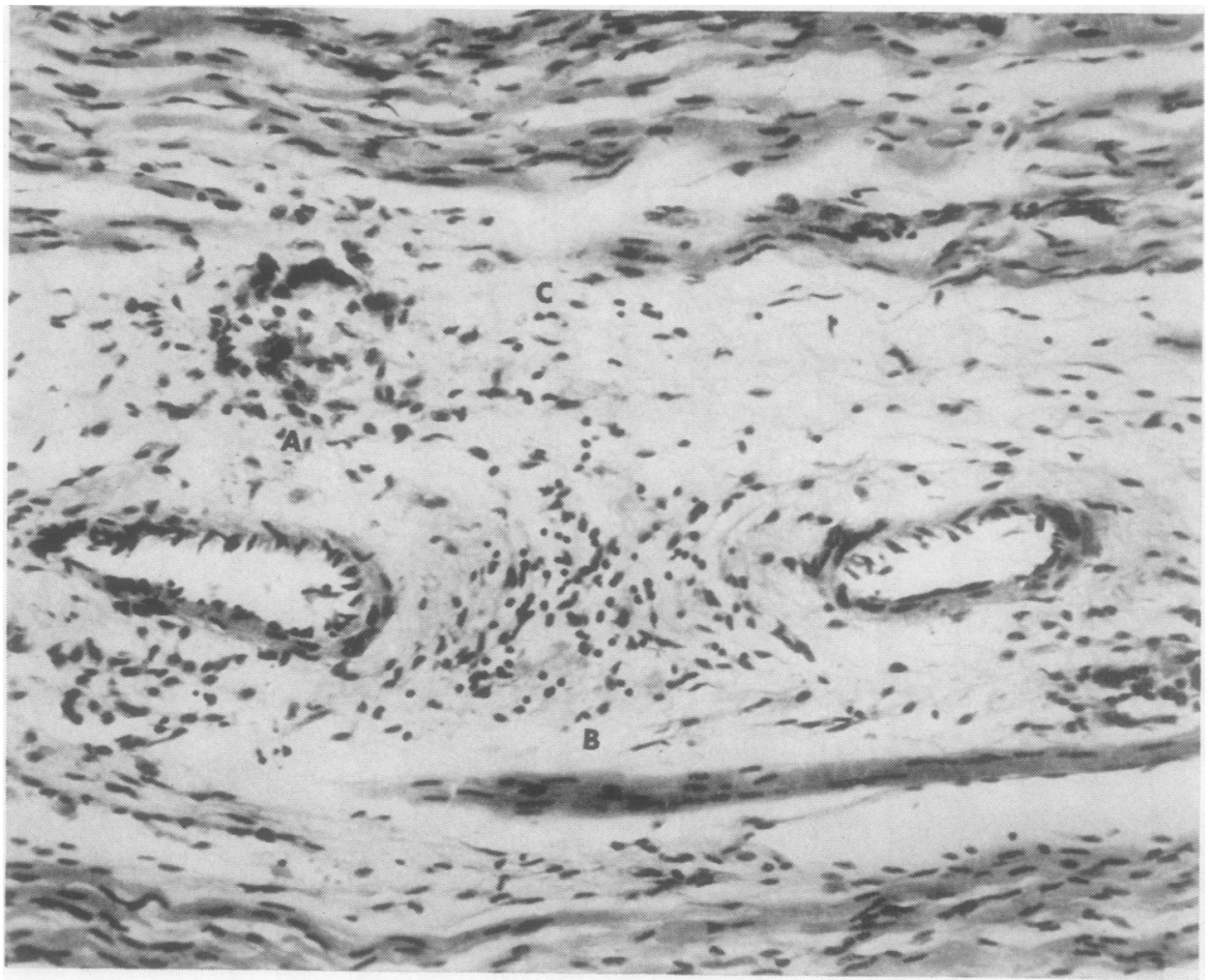

Fig. 24.-Types of damage in rheumatic carditis. Case $1 . \times 375$.

A. Aschoff body forming from lymphatic channel.

B. Area between two vessels, showing damage to connective tissue, with lymphocytic and eosinophilic infiltration.

C. Disappearance of parenchyma in muscle track with persistence of nuclei.

\section{Discussion}

Watson (1835) stated that "The heart is spoiled for its healthy and perfect use by the lymph deposit within it and without it. If it were possible to prevent this destructive effect of the inflammation, that should be our goal, but we can scarcely ever expect to recognize and treat the disease before a diffusion of lymph has taken place." A little more than 100 years later Primak (1940) observed dilated lymph vessels and lymph congestion in the myocardium of patients who died of carditis. Rusznyack, Foldi, and Szabo (1960) appear to have been the first to ask whether an obstructive lymphangitis might be the cause of these findings.

The damage to connective tissue, ground substance, and muscle cells is limited to certain areas in these early cases. These systems are remarkably normal in most areas of the heart. If a toxic substance escaping from the capillaries were causing damage, one would expect to find a more generalized reaction, with widespread involvement of the capillary endothelium. The reaction is limited to sites in the area of well-developed Aschoff bodies and to areas where the pressures are very high-in the vicinity of some of the intramyocardial coronary arteries and at the point of closure of the mitral valve. Here the impact of the oedematous cusps against one another causes a "blister" of vegetation to form (Swift, 1924). No vegetations were seen on the valves at autopsy in Cases 3 and 6.

Death from rheumatic carditis must result from myocardial failure. All students of this subject have been faced with the dilemma posed by this uncontestable fact and the normal appearance of cardiac muscle fibres on microscopic examination. In this series only Cases 1 and 6 gave a hint of generalized damage to the myocardium. In the other cases, except in the region of Aschoff bodies, the appearance of the cardiac muscle is, if anything, better than that in the sections from non-rheumatic hearts of the same age. 


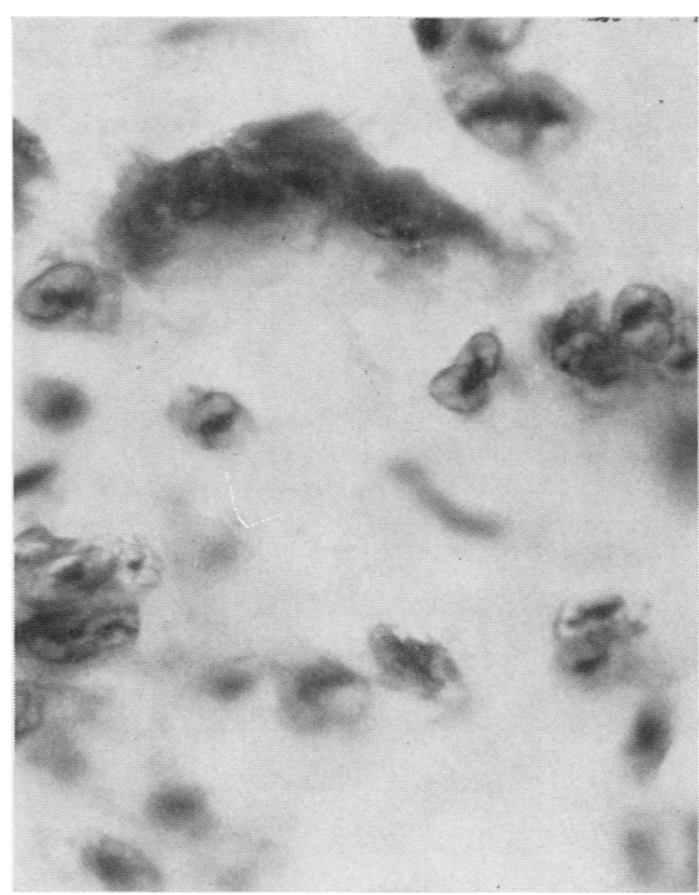

Fig. 25.-Aschoff body in Fig. 24(A) under higher power. Case 1. $\times 1,040$.

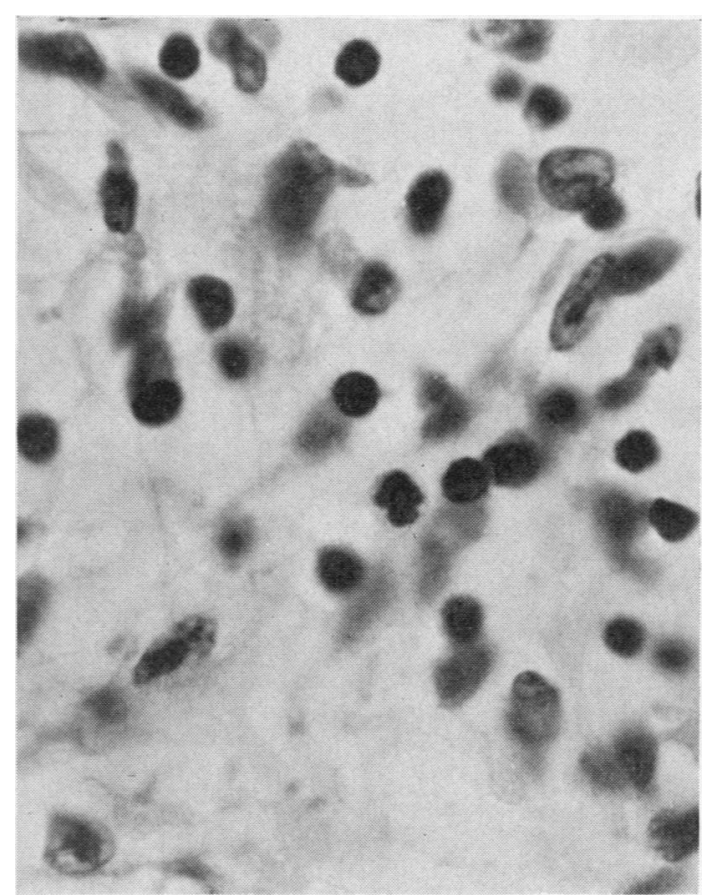

Fig. 26.-Area of damage to connective tissue in Fig. 24(B) under higher power. Case $1 . \times 1,040$.
Changes in the lymphatic system, on the other hand, are present throughout the heart in all these cases. The contrast between the normal myocardium and extensive involvement of the lymphatics is especially striking in Case 3 , where there appears to have been a previous attack. Many of the lymphatic vessels are obliterated-those under the endocardium, those in the pericardium, and those coursing in the myocardium close to the blood vessels, leaving partial cuffs of scar tissue around the latter. As is well known, one attack of carditis predisposes to future attacks. Although lymphatic vessels quickly recanalize after ligation, progressive fibrosis of the system would cause subsequent episodes of acute inflammation to obstruct the lymphatic drainage of the heart more and more readily.

The impairment of myocardial function is not only mechanical because of the oedema, but functional because of disturbances in metabolism caused by the stasis which is caused in its turn by the lymphatic blockage. This is a situation which could perhaps be tolerated by an organ at rest, but in the rapidly beating heart disorder of the com- plicated biochemical mechanisms of contraction must occur long before damage which can be recognized by relatively crude histological procedures.

The sites of occurrence of Aschoff bodies are in part conditioned by mechanical pressure. Those sites where the pressure is high, under the endocardium and in the vicinity of the intramyocardial coronary arteries (where pressures are high in diastole as well as in systole), are relatively frequent sites of granulomata. These lesions are less commonly found in the pericardium, which acts as a loose envelope during systole; in this area the diseased lymphatic endothelial cells do not so often form giant cells. It is also the larger lymphatic channels which show the most pronounced involvement; this suggests that the rheumatic agent may, in fact, reach the heart in a retrograde fashion in these early cases through the lymphatics of the neck and thorax. There is a possibility that the lymph in the intracellular spaces becomes in some manner concentrated when it reaches the larger channels of the heart; a search of the literature has revealed no positive evidence for or against such a concept. 
Cells with "caterpillar" or "owl-eyed" nuclei were seen in sections of non-rheumatic hearts from children of the same age, and were especially noticeable in the heart of a child on whom cardiac massage had been performed immediately before death. They may perhaps result when a cell in one of the phases of mitosis is subjected to great pressure.

Eosinophils are conspicuously absent in early Aschoff bodies; they may, however, be present in great numbers in the most fulminating cases of carditis. They are also present in areas where secondary damage to connective tissue of the heart has occurred. In the earliest case (Case 1) they were found in any number in only two small areas. In one area a small capillary was thrombosed; here there were a few scattered red blood cells lying free in the adjacent interstitial spaces, two degenerating muscle cells, and a moderate infiltration of polymorphonuclear leucocytes, about half of which, by count, were eosinophils. The other area has been described (Fig. 26). There appears to be some product of tissue break-down in the heart which quickly provokes an eosinophilic response.

Many questions remain unanswered. One is the relation of the pathogenesis of the Aschoff body to the formation of the rheumatic subcutaneous nodule. The brain has no lymphatic vessels, although perivascular collections of lymphocytes are found in its substance in chorea. Possibly it is the lymphatic vessels of the meninges which are affected. The question whether the joint manifestations are also a result of an obstructive lymphangitis, and the cause of the many so-called minor manifestations of rheumatic fever (rashes, nosebleeds, abdominal pain) await further study.

The concept of the pathogenesis of rheumatic carditis which has been presented is a return to the original view of Aschoff, who regarded the primary damage in rheumatic carditis as a proliferation of cells in response to a rheumatic virus. The streptococcus appears to be the most common stressing factor in rheumatic fever in the temperate zone; the specific cause of the disease is as yet unknown.

\section{Summary}

(1) The pathology of six cases of fulminating rheumatic carditis has been studied, with three non-rheumatic hearts as controls.

(2) Evidence is presented that the Aschoff body is a diseased lymphatic channel.

(3) Damage to the myocardium and impairment of its function are secondary to an obstructive lymphangitis.
Grateful acknowledgement is made to the following for their contributions to this study: Dr. William Manion, Dr. Peter Vanace, Dr. Maurice Lev, Dr. James Frost, Dr. Enid Gilbert, Dr. Gert Laqueur, Dr. Grace Guinn, Dr. Hans Wigger, Dr. Louis Thomas, Dr. Hugh McGill, Dr. Chandler Stetson, Dr. Norman Cooper, Dr. Pia Vera Cruz, Dr. Dorothy Bocher, Dr. Robert Pollitzer, Dr. Irwin Fuhr, Mrs. Dora Lee Agayoff, Miss Elizabeth Moseley, Mr. William Macy, Mrs. Betty Henry, Mr. Alvin Barnes, Miss Faye Haupt, and Mr. Frank J. Golden.

The National Library of Medicine, the Library of the Clinical Centre National Institutes of Health, the Archibald Church Memorial Library, Northwestern University Medical School, the John Crear Library, and the British Museum Library gave invaluable assistance in the preparation of the bibliography.

Especial appreciation is expressed to Dr. Gert Laqueur, for encouragement and advice in the preparation of the pathological descriptions, and to Mrs. Nina Smith, who carefully read the manuscript and translated certain German publications.

This work was supported by research grant $\mathrm{H} 3554$ of the National Heart Institute of the National Institutes of Health.

\section{REFERENCES}

Aschoff, L. (1904). Verh. dtsch. path. Ges., 8, 46. (1939). Ann. rheum. Dis., 1, 161.

and Tawara, S. (1906). "Die heutige Lehre von den pathologisch-anatomischen Grundlagen der Herzchwache." Fischer, Jena.

Baggenstoss, A. H. (1953). In "Pathology of the Heart", ed. S. E. Gould, p. 679. Thomas, Springfield, Ill.

Besnier, E. (1877). "Rhumatisme Cardiaque." Dict. encloped. Sci. méd., 3 sér., 4, 528.

Bezançon, F., and Weil, M.-P. (1926). Ann. méd. Paris, $19,81$.

Clawson, B. J. (1929). Arch. Path., 8, 664.

-, Bell, E. T., and Hartzell, T. B. (1926). Amer. J. Path., 2, 193.

Dundas, D. (1809). Med.-chir. Trans., 1, 37.

Eulenberg, M. M. (1854). Med. Ztg. Berl., 23, 125, $129,133,139$.

Fahr, T. (1930). Beitr. path. Anat., 85, 445.

Fraenkel, E. (1912). Ibid., 52, 597.

Gallavardin, L. (1908). Lyon méd., 110, 753.

Geipel, P. (1905). Dtsch. Arch. klin. Med., 85, 75.

Gross, L., and Ehrlich, J. C. (1934). Amer. J. Path., $10,467$.

—, Loewe, L., and Eliasoph, B. (1929). J. Exp. Med., 50, 41 .

Huzella, T. (1914). Verh. dtsch. path. Ges., 17, 470.

Itard, J.-I. (1824). Thèse de Paris ["Considérations sur le rhumatisme du coeur"].

Jacki, E. (1919-20). Frankfurt Z. Path., 22, 82.

Janot, A. (1902). Thèse de Paris ["Contribution à l'étude de la myocardite rhumatismale aiguë"]. 
Jenner, E. (1789). In W. R. LeFanu (1951). “A Biobibliography of Edward Jenner”, p. 17. Harvey and Blythe, London.

Klinge, F. (1933). Ergebn. allg. Path. path. Anat., 27,1 .

Letulle, M., Bezançon, F., and Weil, M.-P. (1926). Ann. méd. Paris, 19, 117.

MacCallum, W. G. (1924). Bull. Johns Hopk. Hosp., 35, 329.

(1925). J. Amer. med. Ass., 84, 1545.

McEwen, C. (1932). J. exp. Med., 55, 745.

Murphy, G. E. (1943). Bull. Hist. Med., 14, 123. (1960). "Nature of Rheumatic Heart Disease". Williams and Wilkins, Baltimore.

Odier, L. (1806). "'Lezioni di medicina pratica". Trans. A. Dolcini, pp. 50, 194. Sonzogni, Bergamo.

- (1811). "Manuel de médecine pratique", 2nd ed., p. 254. Paschoud, Paris.

Paul, J. R. (1928). Medicine (Baltimore), 7, 383.

Patek, P. R. (1939). Amer. J. Anat., 64, 203.

Peter (1891). Sem. méd. (Paris), 11, 93.

Pitcairn, D. (1707). Quoted by M. Baillie (1797). In "The Morbid Anatomy of Some of the Most Important Parts of the Human Body", 2nd ed., p. 46. Johnson, London.
Poynton, F. J. (1899). Med.-chir. Trans., 82, 355.

Primak, F. (1940). Starost, Kiev., p. 97. Quoted by Rusznyak and others (1960), p. 578.

Rheumatism and Arthritis Review (1962). Ann. intern. Med., 56 (5), Part 2.

Roberts, J. T. (1959). In "Cardiology: an Encyclopedia of the Cardiovascular System", ed. A. A. Luisada, vol. 1, p. 85. Blakiston Division, McGraw-Hill, New York, Toronto, London.

Rusznyak, I., Foldi, M., and Szabo, C. (1960). "Lymphatics and Lymph Circulation", trans. A. Deak and J. Fésus, p. 578. Pergamon Press, New York.

Sacks, B. (1926). Amer. Heart J., 1, 750.

Saigo, Y. (1908). Beitr. path. Anat., 44, 296.

Swift, H. F. (1924). J. exp. Med., 39, 497.

Talalajew, W. T. (1929). Klin. Wschr., 8, 124.

Thorel, C. (1910). Ergebn. allg. Path. patk. Anat., abt. II, vol. 14, p. 133.

Wagner, B. M., and Tedeschi, C. G. (1955). Arch. Path., 60, 423.

Watson, T. (1835). Lond. med. Gaz., 16, 164.

Whitman, R. C., and Eastlake, A. C. (1920). Arch. intern. Med., 26, 601.

Wilson, M. G. (1940). "Rheumatic Fever". Commonwealth Fund, New York.

\section{APPENDIX}

\section{Five Detailed Case Reports}

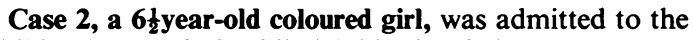
Children's Hospital, Philadelphia, in 1958.

Past History.- She had had measles, mumps, and whooping cough in 1955-56.

History of Present Illness.-She was well until 3 to 4 weeks before admission, when she developed a cough and sore throat followed by intermittent fever unaffected by oral penicillin. Her ankles swelled intermittently, but were not tender. The dorsa of the feet and the abdomen had become swollen 2 to 3 weeks before. 4 days before admission her eyes became puffy and on the day of admission the right wrist became painful and swollen.

She had had rapid breathing for 2 weeks, cough for 4 weeks, and blood-streaked sputum 2 days before admission. There was no haematuria, dysuria, or frequency of micturition. A skin-rash had been present on the abdomen for 3 days.

Physical Examination.-Temperature $101^{\circ}$ F., pulse $162 / \mathrm{min}$., blood pressure $90 / 60$. There was pallor, bilateral pretibial oedema and oedema of dorsa of feet. AB was diffuse, no thrills. Muffled heart sounds, I and II gallop rhythm, loud low-pitched systolic murmur maximal at the 5th left intercostal space. There was a questionable short diastolic murmur maximal at the tricuspid area. There was flaring of the nostrils. The percussion note was diminished at both bases and at the right mid-zone. There were rhonchi at both bases, and questionable bronchial breathing at the mid-zone.

The liver was enlarged 2 in. below the right costal margin and soft. There was shifting dullness on both flanks. The joints were painful and tender, with hot swellings of fingers, wrist, and elbow on the right side. Both ankles were swollen. The left knee and left hip were tender and painful.

Clinical Impression.-Acute rheumatic carditis, in failure, with questionable rheumatic pneumonia and lobar pneumonia.

Treatment.-Oxygen, aqueous penicillin, digitalin, aspirin, thiomerin, restricted fluid intake.

Laboratory Tests.-Hb 6.6 g. per cent.; white blood count 29,800 (85 per cent. neutrophils, 14 per cent. lymphocytes). Erythrocyte sedimentation rate $34 \mathrm{~mm}$./ 1 st hr.

Electrocardiogram showed changes indicative of myocarditis.

$X$ rays showed enlarged cardiac shadow compatible with the enlarged heart of pericarditis, congestive changes in the lung fields, and possible pleural fluid accumulations.

Course in Hospital.-During the next 48 hours the patient improved, with subsidence of fever, joint swellings, and tenderness, but she began to vomit and the aspirin and digitalin were discontinued. She worsened markedly 
for the next 24 hours with dyspnoea and a distressing cough. $X$ rays of the chest revealed increasing lung involvement. On the fifth day she had two spells of apnoea and the blood pressure fell to 98/60. That evening her respirations increased to $80 / \mathrm{min}$. She suddenly complained of dizziness and became unconscious with frothy foam at the lips. Despite all resuscitative measures she died at 10 p.m.

It should be noted that on the day before death the patient was started on intramuscular cortisone $300 \mathrm{mg}$. (75 mg. 6-hrly).

Final Diagnosis.-Rheumatic pancarditis.

Case 3, a 4-year-old coloured girl, was admitted to the Louisiana State University School of Medicine, having complained of foot pain with a swollen ankle 4 days before admission.

Examination.-On admission her temperature was $104 \cdot 8^{\circ} \mathrm{F}$., pulse $160 / \mathrm{min}$., blood pressure $86 / 80$. Nothing was otherwise abnormal. The white blood cell count was 18,360 , and the corrected erythrocyte sedimentation rate $34 \mathrm{~mm} . / 1 \mathrm{st}$ hour. The electrocardiogram was negative.

Course.-She became dyspnoeic and developed gallop rhythm, and was given digitalin and oxygen. She died 18 days after admission.

Autopsy.-The heart weighed 110 g. (expected 73 g.) and was dilated; no vegetations were seen on the valves. The lungs weighed $450 \mathrm{~g}$. together (expected $175 \mathrm{~g}$.) and were diffusely consolidated; on microscopic section they showed a severe interstitial pneumonia.

Final Diagnosis.-Rheumatic pancarditis.

Case 4, a 10-year-old white boy, was admitted to the New York University Medical Centre. He had been well up to 7 weeks before admission when he developed fever $102^{\circ} \mathrm{F}$., and had been treated first with sulphonamides and then with penicillin to which he developed a marked reaction. A murmur was noted on the 10th day of illness. He continued to have fever, and in the fifth week developed signs and symptoms of heart failure and was given digitalin. 3 days before admission he had become cyanotic and developed a persistent cough. He lost $15 \mathrm{lb}$. during this illness.

Examination.-He was critically ill, dyspnoeic, orthopnoeic, and cyanotic. The heart sounds were irregular, with a harsh systolic murmur at the base, and rales were noted at the base of the lungs.

Laboratory Tests.-All were within normal limits, including the white blood count and differential count, except for a raised erythrocyte sedimentation rate (35 mm./1st hour) and a total protein of 5.7 per cent.

Blood culture was negative.

The erythrocyte count was $4,690,000$ with $\mathrm{Hb} 16 \cdot 5$, and $3,830,000$ with $\mathrm{Hb} 8 \cdot 5$.

An electrocardiogram revealed a right axis deviation and complete auricular-ventricular block.

A chest $x$ ray revealed probable broncho-pneumonia and enlarged heart.
Clinical Impression.-Acute rheumatic heart disease; congestive heart failure; broncho-pneumonia.

Course.-The temperature varied from 100 to $102^{\circ} \mathrm{F}$. and rose terminally to $104^{\circ}$. Despite all therapy he died on the 13th day in hospital.

Final Diagnosis.-Acute rheumatic myocarditis; acute rheumatic valvulitis: tricuspid, mitral, and aortic valves; acute serofibrinous pericarditis; bilateral pneumonitis due to rheumatic fever.

Case 5, a 5-year-old coloured boy, was admitted to the Children's Hospital of the District of Columbia. He had been well until about 4 weeks before admission when he developed an erythematous rash over the arms and legs, which lasted for 2 days and recurred 2 weeks later with migratory joint pain, swelling of knee and ankle joints, and fever.

Examination.-He was an irritable boy with a palpable systolic thrill over the left side of the sternum, apex beat in the 5th intercostal space within nipple line, grade II harsh systolic murmur over the entire precordium, but loudest over the apex, split P2 and A2. There was pitting oedema of both ankles.

Laboratory Tests.-Negative, except for anaemia 8.6 g. $/ 100 \mathrm{ml}$., and antistreptolysin-O titre 250 Todd units.

Chest $x$ ray revealed increased pulmonary vascularity and an enlarged cardiac silhouette; the liver appeared enlarged.

Electrocardiogram tracings were interpreted as showing AV block and left ventricular hypertrophy.

Clinical Impression.-Rheumatic fever and carditis; congestive heart failure; broncho-pneumonia.

Course.-Despite treatment with penicillin, salicylates, steroids, and digitalin as well as thiomerin and Diamox, his condition failed to improve: intercurrent bronchopneumonia developed and he died on the 28 th day in hospital.

Final Diagnosis.-Rheumatic fever and pancarditis; pneumonitis, bilateral, rheumatic; acute passive congestion of liver, spleen, kidneys and adrenals; lymphadenitis.

Case 6, a 3-year-old Indian boy, was admitted to the Belcourt Indian Hospital, North Dakota, with cough and fever. He had had diarrhoea and vomiting for 2 days, but this had ceased on the day of admission. He had complained of earache on the morning of admission. He had been irritable the previous night and his mother had noted painful swelling of the ankles on the morning of admission.

Past History.-There were no previous illnesses. He had had a fever 3 weeks before admission, when a heart murmur was noted for the first time, but the throat was not inflamed, and the white blood count and differential counts were not remarkable. He had been treated with aspirin and chloramphenicol and did not not return for follow-up evaluation of the heart murmur. There was no history of allergies or immunizations. 
Examination showed he was W.D. W.N. and very irritable, with a temperature of $103 \cdot 4^{\circ} \mathrm{F}$. The right TM was injected at its superior margin. The left TM was clear. The pharynx was clear. There were muffled rhonchi and rales throughout the lung fields. There were mild intercostal retractions. There was a Grade III to IV systolic murmur over the precordium, loudest at the apex. There was tachycardia of 180 . The abdomen and extremities showed nothing remarkable except for puffy swelling around the ankles which seemed to be tender. However, it was very difficult to evaluate this because of his extreme irritability.

Laboratory Tests.-White blood count 14,000 (75 neutrophils, 2 bands, 18 lymphocytes, 3 monocytes, 2 basophils). Erythrocyte sedimentation rate $34 \mathrm{~mm}$./ 1st hour, corrected to 19 . Haematocrit $33, \mathrm{Hb} 8 \cdot 5 \mathrm{~g}$.

$X$ rays showed a rather light patchy infiltrate extending from the hilar regions bilaterally.

Electrocardiogram showed a regular sinus tachycardia with a 12 PR interval. The QRS axis was about 70.

Clinical Impression.-Rheumatic fever with possible rheumatic pneumonia.

Course.-He was placed on aspirin and procaine penicillin 600,000 units every $12 \mathrm{hrs}$. That evening the rectal temperature dropped to $100^{\circ} \mathrm{F}$. and the pulse rate to 138. Attempts to hear the heart murmur were unsuccessful presumably because of respiratory noises. However, the child seemed to be more comfortable and less irritable. In the early morning the respirations became more rapid (about 50-60/min.) and the pulse rate 150-158. The child was moaning and rubbing his abdomen as if in pain, but there was no apparent distension or hardness of the abdomen. The urinary output was good. Later in the morning his condition seemed to worsen despite a normal temperature; the pulse rate continued to be rapid though it was less than on admission.

The electrocardiogram showed no essential changes. He seemed to be having more respiratory difficulty and was placed in the croupette with alevair. He was also given $0.5 \mathrm{~g}$. streptomycin intramuscularly and was placed on $2 \mathrm{dr}$. chloramphenicol 4-hrly. The liver was enlarged 2 to 3 finger breadths below the right costal margin. Rales were more prominent in the bases of the lungs. There was no swelling of ankles or feet and no joint tenderness could be demonstrated on PE. He was placed on digoxin $0.5 \mathrm{mg}$. stat and was to receive two more doses of $0.2 \mathrm{mg}$. 8-hrly.

At 3.45 p.m. he had alternating periods of stupor and increased restlessness with purposeless movement of the hands, arms, and legs, and began to thrash about in bed. The pulse rate was 140 , and respirations $60 / \mathrm{min}$. Auscultation of the lungs revealed much more prominent rales and rhonchi and he began to foam at the mouth. Suddenly his heart stopped, and mouth-to-mouth respiration and cardiac massage were of no avail.

Final Diagnosis.-Acute rheumatic fever, valvulitis, myocarditis, and pericarditis; severe fatty degeneration of the heart; focal rheumatic pneumonia with hyaline membranes.

\section{L'origine des nodules d'Aschoff}

\section{RÉSUMÉ}

(1) On étudia l'anatomie pathologique de six cas de cardite rhumatismale fulminante et de trois coeurs non-rhumatismaux comme témoins.

(2) On démontre que le nodule d'Aschoff est un canal lymphatique morbide.

(3) La lésion du myocarde et le dérangement de sa fonction sont secondaires a une lymphangite oblitérante.

\section{El origen de los nódulos de Aschoff}

\section{SuMARIO}

(1) Se estudió la anatomia patológica de seis casos de carditis reumática fulminante, con tres corazones nonreumáticos como testigos.

(2) Se presenta evidencia de que el nódulo de Aschoff es un canal linfático mórbido.

(3) La lesión del miocardio y el desarreglo de su función son secundarios a una linfangitis obstructiva. 